\title{
The genus Camelina (Cruciferae) in Mongolia and China reviewed on the basis of herbarium materials from the Institute of General and Experimental Biology of the ASM (UBA) and the Komarov Botanical
} Institute (LE)
DOI: 10.30901/2227-8834-2020-3-163-165 (cc) BY

УДК 581.6:581.52:581.54:581.95

Поступление/Received: 09.06.2020

Принято/Accepted: 21.09.2020

\author{
Род рыжик - Camelina (Cruciferae) \\ Монголии и Китая по материалам \\ гербариев Института общей \\ и экспериментальной биологии АНМ \\ (UBA) и Ботанического института \\ им. В.Л. Комарова РАН (LE)
}

\author{
V. I. DOROFEYEV ${ }^{1 *}$, U. ENKHMAA ${ }^{2}$ \\ ${ }^{1}$ Komarov Botanical Institute of the RAS, \\ 2 Professora Popova Street, \\ St. Petersburg 197376, Russia \\ *๙vdorofeyev@yandex.ru \\ ${ }^{2}$ Institute of General and Experimental Biology of the \\ Academy of Sciences of Mongolia, \\ Enkhtaivany Prospekt, Ulaanbaatar, Mongolia \\ - ganboldenebish@yahoo.com
}

Herbarium collections of the genus Camelina preserved at the Institute of General and Experimental Biology of the Academy of Sciences of Mongolia (UBA) and the Komarov Botanical Institute of the Russian Academy of Sciences (LE) were studied. The collections of these Herbaria contain materials of 3 species from Mongolia (C. caucasica (Sinsk.) Vass., C. sativa (L.) Crantz, C. sylvestris Wallr.) and 4 from China (C. sativa, C. linicola Schimp. et Spenn., C. microcarpa Andrz., C. sylvestris).

Key words: Camelina microcarpa, Camelina sylvestris, Camelina sativa, Camelina linicola, Camelina caucasica, Brassicaceae, geographical distribution.
Изучены гербарные коллекции рода Camelina Crantz (Cruciferae) Института общей и экспериментальной биологии AНM (UBA) и Ботанического института имени В.Л. Комарова PAH (LE). В фонтах упомянутых гербариев хранятся материалы по трем (C. caucasica (Sinsk.) Vass., C. sativa (L.) Crantz, C. sylvestris Wallr.) видам этого рода из Монголии и четырем (C. sativa, C. linicola Schimp. et Spenn., C. microcarpa Andrz., C. sylvestris) с территории Китая.

Ключевые слова. Camelina microcarpa, Camelina sylvestris, Camelina sativa, Camelina linicola, Camelina caucasica, Brassicaceae, географическое распространение.
To discuss the species diversity within the genus Camelina Crantz in Mongolia and China, we studied not very large herbarium holding at the Institute of General and Experimental Biology of the Academy of Sciences of Mongolia (UBA, Ulaanbaatar) and the Komarov Botanical Institute of the Russian Academy of Sciences (LE, St. Petersburg). At the same time, these collections made it possible to clarify the diversity of Camelina spp. in the Mongolian and Chinese florae. Some gaps were filled in the species diversity of Mongolia. The most recent regional revision of cruciferous plants in Mongolia (German, 2015) did not cite C. caucasica (Sinsk.) Vass. The diversity of Camelina spp. in the Chinese vegetation was doubled: previously, only two species had been recognized (Zhou et al., 2001).

Supplements to the Camelina diversity in East Asia are primarily associated with the still remaining ignorance about the existing morphological boundaries between the pairs of species: C. microcarpa Andrz. with C. sylvestris Wallr., and C. sativa (L.) Crantz with C. linicola Schimp. et Spenn., although they are clearly obvious not only from the type specimens.

The diversity of the genus Camelina is not too convincingly exposed in the discussions on geographical and phylogenetic data contained in a quite recent publication by Žerdoner Čalasan et al. (2019). The authors expressly emphasized the rather strange variations in C. microcarpa (as they understood them): for example, 4 ribotypes (two western and two eastern), and C. sativa which was represented in the said publication by two ribotypes. In fact, those studies showed a clearly manifested, geographically and phylogenetically determined richness of species within C. microcarpa aggr., once described as ser. Microcarpae, and later recognized as a section (Dorofeyev, 1996; 2019).

No less obvious is the species diversity of $C$. sativa aggr. (ser. Camelina) (Dorofeyev, 1996). It is impossible not to notice this fact while scrutinizing the cited publication. A drawback in the study by the previous authors is that C. rumelica Velen. was incorporated into the diversity of C. microcarpa, which is detrimental to the true understanding of the diversity of the genus in question and does not allow the readers to see and evaluate its general structure.

The genus Camelina is not natural for Mongolia or China. This fact is obvious not only from the records on the herbarium sheets at LE and UBA, but also from the results of our long-term observations in Siberia and Mongolia. Anthropogenically introduced adventive plants, scantily represented in both herbaria at Ulaanbaatar and St. Petersburg, still reflect the existing, albeit small, diversity of species whose morphological information is not yet available in old or new publications containing reviews of these cruciferous plants in these two countries (Grubov, 1982; Zhou et al., 2001; German, 2009; 2015; etc.). 
It was established on the basis of herbarium materials reviewed in the said publication that the Camelina diversity in East and Central Asia comprises 5 species: C. microcarpa, C. sylvestris, C. sativa, C. linicola and C. caucasica. The first two are not very frequent elements of the segetal flora. Their renewal and existence in plant communities take place in a natural way.

The remaining three species (cultivars) cannot independently and constantly reproduce themselves in the mentioned florae. Over time, their presence in these florae, due to natural reasons, declines, and without proper concomitant agricultural practices they can die out within a few years. These processes are quite evident, for example, in Eastern Europe, where in the late 20th century Camelina had not been planted as an oilseed crop for decades.

The morphological features that distinguish the discussed species are quite obvious, although they are constantly ignored (Žerdoner Čalasan et al., 2019). For example, C. microcarpa and C. sylvestris have relatively small pearshaped fruits. In the first species, the top of the fruit is succise, in the second one it is attenuate.

Unlike the previous species, the fruit of $C$. sativa is 1.5 times larger than theirs and slightly attenuated at the top. C. caucasica has a distinctive fruit, depressed at the sides, deformed from side of the frame, slightly attenuated from above. This feature in the fruit structure evolved, on the one hand, in the process of the fruit's asymmetric development, and on the other, as a result of targeted selection of thinvalve forms, most convenient for threshing. In contrast to C. caucasica, the fruit of C.linicola is characterized by a markedly blunted tip of the silicle.

\section{C. linicola Schimp. et Spenn.}

[Северо-восточный Китай] Маньчжурия, ст. Туаченту Кит[итайско]-В[осточной] ж[елезной] д[ороги], 16 VII 1905, П. Егоров (LE!) [China, Manchzhuria, Tauchentu Railway Station, 16 VII 1905, P. Egorov]

\section{C. caucasica (Sinsk.) Vass.}

[Монгольская Народная Республика] Ховсгол аймаг, Хонгор бригад, Туршлагын талвай, Тариалангийн с.а.а. (UBA!) [Mongolia, Khovsgol Aimak]

Монгольская Народная Республика, Центральный аймак, Бату Сумбур сомон, долина р. Хары близ сомона, опытный пункт Комитета наук, комплексные луга в пойме р. Хары, VII 1944, В. Ф. Шубин (LE!) [Mongolia, Central'nyi Aimak, Batu Sumbur Somon, VII 1944, V. F. Shubin]

[Монгольская Народная Республика] Монгол Дагуур: Сэлэгэ аймаг, Дарханы с.а.а., тариалангийн талбайгаaс, 10 VIII 1966, Г. Цэрэнбалжид, И. Санчир (UBA!) [Mongolia, Selenge Aimak, Darkhany Somon, 10 VIII 1966, G. Cerenbalzhin, I. Sanchir]

\section{C. sativa (L.) Crantz}

[Северо-восточный Китай] Маньчжурия, бл. ст. ж.д. Цунь, 26 VI 1902, №1018, Д. Литвинов (LE!) [China, Manchzhuria, Cun' Railway Station, 26 VI 1902, D. Litvinov]

[Северо-восточный Китай] Маньчжурия, западн. Хангайские горы, бл. ст. ж.д. Джалантунь, сорное, 14 VIII 1902, №2558, Д. Литвинов (LE!) [China, Manchzhuria, West of Khangaj Mnts, Dzhalangun' Railway Station, 14 VIII 1902, №2558, D. Litvinov]

КНР [Китайская Народная Республика, Манчжурия], Хэйлунцзянская пров., уезд Хума, около дер. Ванхада, 210 м, на берегу речки под горой, 15 VII 1950 , №136, Chu Yu-chang, Chao Ta-chang (LE!) [China, Man- chzhuria, Kheilunczjanskaja Prov., Khuma Diestr., Vankhada Village, 15 VII 1950, №136, Chu Yu-chang, Chao Tachang].

Монгольская Народная Республика, Арахангайский аймак, Тувшурульх сомон, государственное животноводческое хозяйство в 45 км к юго-востоку от аймака, посевы, 14 VIII 1951, А. В. Калинина (LE!) [Mongolia, Arakhangaj Aimak, Tuvshuryl'kh Somon, 14 VIII 1951, A. V. Kalinina]

\section{C. sylvestris Wallr.}

[Китайская Народная Республика, Джунгария] Iter Turkestanicum, ... Kuldscha, 30 VI 1877, A. Regel (LE!) [China, Dzhungaria, Iter Turkestanicum, ... Kuldscha, 30 VI 1877, A. Regel]

[Китайская Народная Республика, Джунгария] Iter Turkestanicum, ... Kutentass, 14 IV 1877, A. Regel (LE!) [China, Dzhungaria, Iter Turkestanicum, ... Kutentass, 14 IV 1877, A. Regel]

[Китайская Народная Республика, Джунгария] Iter Turkestanicum, Chojur-Sumun nidl. ... Kuldscha, 27 V 1877, A. Regel (LE!) [China, Dzhungaria]

[Китайская Народная Республика, Джунгария] Iter Turkestanicum, Linke Iliseite nidwestl. ... Kuldscha, $29 \mathrm{~V}$ 1877, A. Regel (LE!) [China, Dzhungaria]

Синьцзянская комплексная экспедиция Академии наук Китайской Народной Республики 1956-1959 г.г. Китайская Народная Республика, Синьцзян-Уйгурская автономная область, В. Тынь-Шань, сев. склон г. Урумчи, дол. р. Урумчинки, близ гост[иницы] «Урумчи», галечная надлуговая терраса, среди посадки Ulmus pumila, 30 VI 1957, №10A, A. А. Юнатов (LE!) [China, Sincshan'-Ungur Autonomic Prov., Urumchi, 30 VI 1957, №10A, A. A. Yunatov]

Почвенно-агрономический отряд Монгольской экспедиции Академии наук СССР. Сев. Монголия, среднее течение р. Селенги, поля госхоза им. Коминтерн, в посеве овса на 3 террасе, 13 VIII 1931, №128, Н. Л. Десяткин (LE!) [Mongolia, average flow of Selenga River, 13 VIII 1931, №128, N. L. Desjatkin]

Монгольская Народная Республика, Хобдосский аймак, Булугун сомон, хр. Байтаг-Богдо-нуру, северный склон, ущелье Улясту гола, в 3-4 км от устья, по берегу у воды, 18 IX 1948, №5524, В. И. Грубов (LE!) [Mongolia, Bulugun Somon, Baitag-Bogdo-nuru Range, 18 IX 1948, №5524, V. I. Grubov]

[Монгольская Народная Республика] Монгол Дагуур: Сэлэнгэ аймаг, Шаамар сум-нэгдал, ...... , 25 VI 1977, №1257, Б. Мощак, Ш. Дариймаа (UBA!) [Mongolia, Selenge Aimak, Shaamar Somon, 25 VI 1977, №1257, B. Mostchak, Sh. Darimaa]

\section{C. microcarpa Andrz.}

[Китайская Народная Республика, Джунгария] Iter Turkestanicum, Kuldscha, 3 V1877, A. Regel (LE!) [China, Dzhungaria, Iter Turkestanicum, Kuldscha, 3 V 1877, A. Regel]

[Китайская Народная Республика, Джунгария] Iter Turkestanicum, pr. Kuldscha, 8 V 1877, A. Regel (LE!) [China, Dzhungaria, Iter Turkestanicum, pr. Kuldscha, $8 \mathrm{~V} 1877$, A. Regel] (2 specimena)

[Китайская Народная Республика, Джунгария] Iter Turkestanicum, Piluschi, bei Kuldscha, 17 V 1877, A. Regel (LE!) [China, Dzhungaria, Iter Turkestanicum, pr. Kuldscha, 17 V 1877, A. Regel]

[Китайская Народная Республика, Джунгария] Iter Turkestanicum, Chojur-Sumun ad fl. Ili, 27 V 1877, A. Regel (LE!) [China, Dzhungaria, Iter Turkestanicum, Chojur-Sumun ad fl. Ili, 27 V 1877, A. Regel] 
[Китайская Народная Республика, Джунгария] Iter Turkestanicum, Kuldscha, 30 VI 1877, A. Regel (LE!) [China, Dzhungaria, Iter Turkestanicum, Kuldscha, 30 VI 1877, A. Regel] (3 specimena)

[Китайская Народная Республика, Джунгария] Iter Turkestanicum, Dschagastai, 7 VIII 1877, A. Regel (LE!) [China, Dzhungaria, Iter Turkestanicum, Dschagastai, 7 VIII 1877, A. Regel]

[Китайская Народная Республика, Джунгария] Iter Turkestanicum, Kuldscha, 12 VI 1877, A. Regel (LE!) [China, Dzhungaria, Iter Turkestanicum, Kuldscha, 12 VI 1877, A. Regel]
Работа выполнена в рамках реализации государственного задания согласно плану НИР Ботанического института им. В.Л. Комарова РАН (тема № AAAA-A19119031290052-1 - Сосудистые растения Евразии: систематика, флора, растительные ресурсы).

The work was carried out as part of the implementation of the State Task according to the research plan of the Komarov Botanical Institute of the RAS (No.AAAAA19-119031290052-1 - Vascular plants of Eurasia: taxonomy, flora, plant resources).

\section{References/Литература}

Dorofeyev V.I. Camelina (Cruciferae, Brassicaceae): structure of genus and list of species. Vavilovia. 2019;2(2):3-24. [in Russian] (Дорофеев В.И. Рыжик - Camelina (Cruciferae, Brassicaceae): внутриродовая структура и видовой состав. Vavilovia. 2019;2(2):3-24). DOI: 10.30901/26583860-2019-2-22

Dorofeyev V.I. Genus Camelina (Brassicaceae) of the Caucasian flora. Botanicheskii zhurnal = Botanical Journal. 1996;81(8):95-99. [in Russian] (Дорофеев В.И. Род Camelina (Brassicaceae) во флоре Кавказа. Ботанический журнал. 1996;81(8):95-99).

German D.A. Cruciferae (Brassicaceae): Alternative treatment for the "Conspectus of the vascular plants of Mongolia” (2014). Turczaninowia. 2015;18(2):39-67. DOI: 10.14258/turczaninowia.18.2.4

German D.A. New data on the species composition and distribution of Mongolian Cruciferae. Botanicheskii Zhurnal = Botanical Journal. 2009;94(8):1149-1158. [in Russian]
(Герман Д.А. Новые данные о видовом составе и распространении крестоцветных (Cruciferae) Монголии. Ботанический журнал. 2009;94(8):1149-1158).

Grubov V.I., Yunatov A.A. The main features of the flora of the Mongolian People's Republic in connection with its zoning. Botanicheskii zhurnal = Botanical Journal . 1952;37(1):45-64. [in Russian] (Грубов В.И., Юнатов А.А. Основные особенности флоры Монгольской Народной Республики в связи с ее районированием. Ботанический журнал. 1952;37(1):45-64).

Urgamal M., Oyuntsegtseg B., Nyambayar D., Dulamsuren Ch. Conspectus of the vascular plants of Mongolia. Ulaanbaatar; 2014.

Žerdoner Čalasan A., Seregin A.P., Hurka H., Hofford N.P., Neuffer B. The Eurasian steppe belt in time and space: Phylogeny and historical biogeography of the false flax (Camelina Crantz, Camelineae, Brassicaceae). Flora. 2019;260:151477. DOI: 10.1016/j.flora.2019.151477

Zhou H., Lu L., Yang G., Al-Shehbaz I.A. Camelina Crantz. In: Flora of China. Vol. 8. Beijing; St. Louis; 2001. p.189.
Прозрачность финансовой деятельности / The transparency of financial activities

Авторы не имеют финансовой заинтересованности в представленных материалах или методах.

The authors declare the absence of any financial interest in the materials or methods presented.

\section{Для цитирования / How to cite this article}

Дорофеев В.И., ЭнхмааУ. Род рыжик - Camelina (Cruciferae) Монголии и Китая по материалам гербариев Института общей и экспериментальной биологии AHM (UBA) и Ботанического института им. В.Л. Комарова РAH (LE). Труды по прикладной ботанике, генетике и селекции. 2020;181(3):163-165. DOI: $10.30901 / 2227-8834-2020-3-163-165$

Dorofeyev V.I., Enkhmaa U. The genus Camelina (Cruciferae) in Mongolia and China reviewed on the basis of herbarium materials from the Institute of General and Experimental Biology of the ASM (UBA) and the Komarov Botanical Institute (LE). Proceedings on Applied Botany, Genetics and Breeding. 2020;181(3):163-165. DOI: 10.30901/ 2227-8834-2020-3-163-165
Авторы благодарят рецензентов за их вклад в экспертную оценку этой работы / The authors thank the reviewers for their contribution to the peer review of this work

Дополнительная информация / Additional information

Полные данные этой статьи доступны / Extended data is available for this paper at https://doi.org/10.30901/2227-8834-2020-3-163-165

Мнение журнала нейтрально к изложенным материалам, авторам и их месту работы / The journal's opinion is neutral to the presented materials, the authors, and their employer

Авторы одобрили рукопись / The authors approved the manuscript

Конфликт интересов отсутствует / No conflict of interest

ORCID

Dorofeyev V.I. https://orcid.org/0004-0002-3642-197X 